\title{
Action of dietary proteins and amino acids on the rat adrenal gland
}

\author{
By H. N. MUNRO, MARIAN H. STEELE AND W. C. HUTCHISON \\ Institute of Biochemistry, The University, Glasgow
}

\section{(Received 2 I September 1964-Accepted 21 October 1964)}

The adrenal gland is known to be affected by the protein content of the diet. An excessive intake of protein has generally been found to cause adrenal hypertrophy relative to body-weight; in some experiments, an increase in functional activity of the cortex has been demonstrated (see Munro, 1964, for a review of literature). The opposite changes are induced by protein deprivation. Even a short period of protein deficiency leads to reduction in adrenal weight out of proportion to the loss in bodyweight (Munro, Hutchison, Ramaiah \& Neilson, 1962); this occurs partly through a diminution in the number of cells per gland and partly through a reduction in the amounts of certain individual constituents per cell. These effects of dietary protein levels on the adrenal gland appear to be caused by variations in rate of secretion of adrenocorticotrophic hormone (ACTH) from the pituitary gland (Munro et al. 1962; Munro, I964).

There is also evidence that administration of certain amino acids can influence the functional activity of the adrenal cortex. This was first suspected when it was shown that uptake of phosphorus-32 by liver ribonucleic acid (RNA) is markedly stimulated by giving single large doses of glycine, methionine or leucine to rats (Munro \& Mukerji, 1958). Since the action of leucine and of methionine is abolished by adrenalectomy (Munro \& Mukerji, 1962), it was concluded that addition of these two amino acids causes an increased secretion of adrenocortical hormones, which are known to stimulate liver RNA metabolism (Goodlad \& Munro, 1959). This mechanism of amino acid action was confirmed by showing (Munro, Steele \& Hutchison, 1963a) that administration of single large doses of methionine or leucine to intact rats raised the concentration of corticosterone in the plasma; administering several other amino acids in similar doses did not have this effect. This confirms earlier observations by Góth, Lengyel, Bencze, Sávely \& Majsay (I955) on the blood eosinophil count, which has been shown to diminish as adrenocortical secretion increases. After giving methionine or leucine to rats, these authors observed a striking reduction in eosinophil population, whereas other amino acids produced less significant or insignificant changes. It is not known whether the action of amino acids on adrenocortical secretion depends, like the action of dietary protein, on release of ACTH from the pituitary gland.

The investigations recorded here were undertaken in order to compare the effects of dietary protein and of individual amino acids on the adrenal gland and to determine whether both act by increasing AC'TH release. Rats were fed for II days on diets in 
which the nitrogen source was either a nutritionally adequate protein (casein or zein supplemented with tryptophan and lysine), a protein lacking some essential amino acids (unsupplemented zein or gelatin), or a single amino acid (glycine, methionine or leucine). The influences of these nitrogen sources on adrenal size, average cell composition and corticosterone content were determined. The dietary proteins caused parallel changes in adrenal size, cell composition and corticosterone content, the magnitude of the changes being mainly related to the nutritive value of the protein given. The individual amino acids had little influence on adrenal size and general cell composition, but greatly increased the corticosterone content of the gland. Since exogenously administered ACTH increased both gland weight and corticosterone content, it has been concluded that the amount and nutritive quality of the dietary protein influences the rate of ACTH secretion from the pituitary gland, whereas the action of individual amino acids on the adrenal gland probably depends on a different mechanism. A preliminary account of these findings has been published (Munro, Steele \& Hutchison, I $963 b$ ).

\section{EXPERIMEN TAL}

Animals and diets. Albino rats, initially weighing about $15^{\circ} \mathrm{g}$, were housed in individual cages under thermostatic conditions at $25^{\circ}$. The dietary arrangements were modelled on those used in previous experiments in which the diet was supplied in two portions, all of the dietary protein being in the evening meal (Munro \& Naismith, 1953). At 10 am each rat received $2.8 \mathrm{~g}$ glucose and $\mathrm{I} g$ of a vitamin-mineralroughage mixture (Munro, 1949), and at $5 \mathrm{pm}$ it was given $0.4 \mathrm{~g}$ fat, $\mathrm{I} .8 \mathrm{~g}$ carbohydrate (equal parts of glucose and potato starch) and $2 \mathrm{~g}$ casein. These amounts of food are slightly suboptimal but ensure that animals will subsequently consume similar quantities of a protein-free diet completely over an I r-day period.

For an initial 3-day period all the animals were trained to accept the diet described above, which contained an adequate amount of protein. After this period of adjustment, the rats were divided into eight groups, which differed according to the nitrogen source given in the evening (Table $\mathrm{I}$ ). One group received no protein or amino acid, and a second group continued to receive casein. The remaining groups were given either zein supplemented with tryptophan and lysine, or zein alone, or gelatin, or the single amino acid glycine, methionine or leucine. The proteins were given in $2 \mathrm{~g}$ quantities; the amounts of amino acid chosen were the largest that the rats would voluntarily consume over an I I-day period. The different rations were adjusted to provide the same calorie level by varying the carbohydrate content of the evening meal (Table I). Each of these diets was given for I I days, after which the rats were killed in the fasting state on the morning of the 12 th day.

In one series of experiments, rats were given the protein-free diet for I I days, during the last 3 of which they received 5 i.u. adrenocorticotrophic hormone (Cortrophin$\mathrm{ZN}$; Organon Laboratories Ltd) twice daily by intramuscular injection. Animals were killed at the beginning of the injection period and after $\mathrm{I}$ and 3 days, and the adrenal glands were removed for weighing and corticosterone determination.

Removal of organs and analysis for gross constituents. In experiments in which 
analyses of organs for protein, ribonucleic acid (RNA), deoxyribonucleic acid (DNA) and phospholipid were performed, the rats were killed by a blow on the head and the livers and adrenal glands were rapidly excised, cleaned of adhering tissue and weighed. Chemical analyses of the tissue were carried out by procedures previously described (Munro et al 1962).

Table I. Composition of second meal of diets given to rats

\begin{tabular}{|c|c|c|c|c|c|}
\hline \multirow[b]{2}{*}{ Dietary group } & \multicolumn{5}{|c|}{ Constituent of meal } \\
\hline & $\begin{array}{l}\text { Margarine } \\
\text { (g) }\end{array}$ & $\begin{array}{l}\text { Starch } \\
\text { (g) }\end{array}$ & $\begin{array}{c}\text { Glucose } \\
\text { (g) }\end{array}$ & Protein & Amino acid \\
\hline Protein-free & 0.4 & $I \cdot 90$ & $I \cdot 90$ & - & 一 \\
\hline Casein & 0.4 & 0.90 & 0.90 & $2 \mathrm{~g}$ casein & - \\
\hline Zein + try + lys & 0.4 & 0.82 & 0.82 & $2 \mathrm{~g}$ zein & $\left\{\begin{array}{l}0.05 \mathrm{~g} \text { L-tryptophan } \\
0.10 \mathrm{~g} \text { L-lysine }\end{array}\right.$ \\
\hline Zein & 0.4 & 0.90 & 0.90 & $2 \mathrm{~g}$ zein & - \\
\hline Gelatin & 0.4 & 0.90 & 0.90 & $2 \mathrm{~g}$ gelatin & - \\
\hline Glycine & 0.4 & $I \cdot 65$ & $I \cdot 65$ & - & $0.5 \mathrm{~g}$ glycine \\
\hline Methionine & 0.4 & $I \cdot 80$ & $I \cdot 80$ & - & $0.2 \mathrm{~g} \mathrm{DL}-$ methionine \\
\hline Leucine & 0.4 & $I \cdot 65$ & $I-65$ & - & $0.5 \mathrm{~g}$ L-leucine \\
\hline
\end{tabular}

Assay of corticosterone in adrenal glands and in plasma. To study the effect of diet on the corticosterone content of the adrenal glands and the plasma, separate groups of rats were given the diets and were killed by guillotine in order to avoid exciting them. Blood was collected from the severed neck vessels into heparinized tubes. The adrenal glands were rapidly removed, cleaned and weighed.

As soon as possible after killing, the plasma was separated centrifugally from the heparinized blood. The corticosterone content of the plasma was measured by the fluorimetric method of Silber, Busch \& Oslapas (1958) on $0.2-0.5 \mathrm{ml}$ samples of plasma. The samples were initially extracted with 2,2,4-trimethylpentane and then with redistilled methylene chloride. The fluorescence of the final sulphuric acid extract was read on an Aminco-Bowman spectrophotofluorimeter (American Instrument Company, Silver Spring, Maryland, USA); an exciting wavelength of $465 \mathrm{~nm}$ was used, and the fluorescence emitted was read at a wavelength of $530 \mathrm{~nm}$ with the Ilford filter no. 109 recommended by Braunsberg \& James (1960). With each set of estimations, a series of corticosterone standards was treated by the same procedure. Corticosterone samples added to plasma gave an average recovery of $104 \%$.

The same procedure was used to determine the corticosterone contents of the adrenal glands. Both glands from one animal were homogenized with $2 \mathrm{ml} 33 \%(\mathrm{v} / \mathrm{v})$ ethanol (redistilled) in a Potter-Elvehjem homogenizer. After making up to $10 \mathrm{ml}$ with water, duplicate $3 \mathrm{ml}$ samples were taken for corticosterone assay. The same method as for plasma was then applied, except that the initial washing with $2,2,4^{-}$ trimethylpentane was found to be unnecessary and was omitted. 


\section{RESULTS}

The experiments reported here show the effects of various dietary proteins and amino acids on adrenal size and cell composition and their effects on the corticosterone contents of the adrenal gland and blood plasma. The changes observed have been compared with the action of adrenocorticotrophic hormone. Finally, changes in liver composition on the different diets are described.

\section{Table 2. Adrenal cell composition after I I days feeding on a protein-free diet} supplemented with various proteins and amino acids

(Each entry for gland weight is the mean result for eighteen female rats; for ad renal composition, the adrenals of ten rats in each dietary group were analysed separately)

\begin{tabular}{|c|c|c|c|c|c|}
\hline \multirow[b]{2}{*}{$\begin{array}{l}\text { Addition to } \\
\text { protein-free diet }\end{array}$} & \multirow{2}{*}{$\begin{array}{l}\text { Gland weight } \\
\text { (mg/roog } \\
\text { initial } \\
\text { body-weight) }\end{array}$} & \multicolumn{4}{|c|}{ Adrenal composition/mg DNA-phosphorus } \\
\hline & & $\begin{array}{l}\text { Mean } \\
\text { cell wt } \\
\text { (g) }\end{array}$ & $\begin{array}{l}\text { Protein } \\
(\mathrm{mg} \mathrm{N})\end{array}$ & $\begin{array}{c}\text { RNA } \\
(\mathrm{mg} \mathrm{P})\end{array}$ & $\begin{array}{l}\text { Phospholipid } \\
\text { (mg P) }\end{array}$ \\
\hline None & $21 \cdot 0$ & $2 \cdot 21$ & $28 \cdot 6$ & 0.95 & $3 \cdot 78$ \\
\hline Casein & $\begin{array}{c}27.9 \\
(+33 \%)^{*}\end{array}$ & $\begin{array}{c}2.53 \\
(+14 \%)\end{array}$ & $\begin{array}{c}35.8 \\
(+25 \%)^{*}\end{array}$ & $\begin{array}{c}I \cdot I 5 \\
(+2 I \%) *\end{array}$ & $\begin{array}{c}4.52 \\
(+19 \%)\end{array}$ \\
\hline Zein + try + lys & $\begin{array}{c}26 \cdot 9 \\
(+28 \%)^{*}\end{array}$ & $\begin{array}{c}2 \cdot 51 \\
(+14 \%)^{*}\end{array}$ & $\begin{array}{c}33.9 \\
(+19 \%)^{*}\end{array}$ & $\begin{array}{c}x \cdot 13 \\
(+19 \%)^{*}\end{array}$ & $\begin{array}{c}4.30 \\
(+14 \%)\end{array}$ \\
\hline Zein & $\begin{array}{c}24.0 \\
(+14 \%)^{*}\end{array}$ & $\begin{array}{c}2 \cdot 40 \\
(+9 \%)\end{array}$ & $\begin{array}{c}32 \cdot 7 \\
(+14 \%)^{*}\end{array}$ & $\begin{array}{c}1 \cdot 07 \\
(+13 \%) *\end{array}$ & $\begin{array}{c}4.32 \\
(+14 \%)\end{array}$ \\
\hline Gelatin & $\begin{array}{c}22 \cdot 0 \\
(+5 \%)\end{array}$ & $\begin{array}{c}2 \cdot 26 \\
(+2 \%)\end{array}$ & $\begin{array}{c}30.4 \\
(+6 \%)\end{array}$ & $\begin{array}{c}0.96 \\
(+1 \%)\end{array}$ & $\begin{array}{c}3.85 \\
(+2 \%)\end{array}$ \\
\hline Glycine & $\begin{array}{c}24.1 \\
(+15 \%)\end{array}$ & $\begin{array}{c}2 \cdot 32 \\
(+5 \%)\end{array}$ & $\begin{array}{c}31 \cdot 4 \\
(+10 \%)\end{array}$ & $\begin{array}{c}0.99 \\
(+4 \%)\end{array}$ & $\begin{array}{c}3.8 I \\
(+.1 \%)\end{array}$ \\
\hline Methionine & $\begin{array}{c}23.7 \\
(+13 \%)\end{array}$ & $\begin{array}{c}2 \cdot 27 \\
(+3 \%)\end{array}$ & $\begin{array}{c}30.9 \\
(+8 \%)\end{array}$ & $\begin{array}{c}0.98 \\
(+3 \%)\end{array}$ & $\begin{array}{c}4.05 \\
(+7 \%)\end{array}$ \\
\hline Leucine & $\begin{array}{c}22 \cdot 9 \\
(+9 \%)\end{array}$ & $\begin{array}{c}2 \cdot 18 \\
(-1 \%)\end{array}$ & $\begin{array}{c}277 \\
(-3 \%)\end{array}$ & $\begin{array}{c}\mathbf{I} \cdot 06 \\
(+12 \%)\end{array}$ & $\begin{array}{c}3.41 \\
(-10 \%)\end{array}$ \\
\hline $\begin{array}{l}\text { Standard deviation } \\
\text { Smallest difference }\end{array}$ & $\begin{array}{r} \pm 4 \cdot 2 \\
2 \cdot 8\end{array}$ & $\begin{array}{r} \pm 0.25 \\
0.22\end{array}$ & $\begin{array}{r} \pm 4 \cdot 4 \\
3 \cdot 8\end{array}$ & $\begin{array}{r} \pm 0.14 \\
0.12\end{array}$ & $\begin{array}{r} \pm \mathbf{r} \cdot 09 \\
0.98\end{array}$ \\
\hline
\end{tabular}

significant at $5 \%$

level

* Significantly different $(P<0.05)$ from mean for group on protein-free diet.

\section{Adrenal size and cell composition after giving different nitrogen sources}

Table 2 shows measurements of size and composition made on the adrenal glands of female rats fed for I I days on diets in which the nitrogen was provided by nutritionally adequate proteins, by nutritionally inadequate proteins or by single amino acids. The weights of the glands have been expressed as percentages of the animals' initial weights in order to reduce variability. This procedure was adopted because the data published by Donaldson (1924) show that the two adrenal glands of the female rat bear an almost constant ratio to body-weight over the range 100-200 g. The analytical results are expressed in relation to the DNA content of the gland. Since the DNA content of an organ can be used as a measure of cell number (Thomson, Heagy, Hutchison \& Davidson, 1953), this method of expressing the results indicates whether 
changes in diet affect the composition of the average adrenal cell. In our previous studies (Munro et al. I962) average cell composition was found to respond readily to changes in the protein content of the diet. The results have been assessed statistically by analysis of variance; the residual error variance was used to estimate the minimum significant differences between means.

In comparison with animals receiving the protein-free diet, the feeding with casein and with zein supplemented with tryptophan and lysine caused significant increments in the weight of the adrenal glands and also in mean cell weight, protein content and RNA content. The phospholipid content showed a similar trend, but the differences failed to attain significance. Unsupplemented zein caused smaller but still significant increases in adrenal weight and in protein and RNA content of the average adrenal cell; the effect on gland weight was significantly less than that of zein supplemented with tryptophan and lysine. Gelatin had no significant action on adrenal weight or composition. Thus the effects of different dietary proteins on the adrenal gland are largely determined by their nutritive value.

None of the groups receiving single amino acids as their nitrogen source showed significant changes in cell composition from those of the group fed on the protein-free diet. Although glycine caused a significant increase in gland size, this was significantly less than the change caused by feeding with casein or zein supplemented with tryptophan and lysine. It can be concluded that the action of dietary proteins on the size and composition of the adrenal cortex is not related to their contents of glycine, methionine or leucine.

\section{Adrenal and plasma corticosterone levels after giving different nitrogen sources}

In order to determine whether or not adrenocortical function was affected by the proteins and amino acids used in the experiment described above, rats were fed for I I days on diets containing these proteins or amino acids, and the amounts of corticosterone in the gland and in the plasma were then measured. The rats were killed by guillotine in order to minimize excitement. In animals receiving a stock diet, this method of killing gave average plasma corticosterone concentrations in male rats of $26 \mu \mathrm{g} / \mathrm{roo} \mathrm{ml}$, which is similar to reported concentrations (Silber et al. 1958). However, all animals on the experimental diets were found to have considerably higher blood corticosterone levels, presumably associated with the stress of experimentation.

Table 3 shows the total amounts of corticosterone in the two adrenal glands and in the plasma of animals receiving different proteins and amino acids. Casein and zein supplemented with tryptophan and lysine increased the total amount of corticosterone in the gland above the level observed after feeding on a protein-free diet, whereas unsupplemented zein and gelatin did not alter the corticosterone content. This indicates that the effect of dietary protein on adrenal corticosterone content is dependent on the nutritive value of the protein. On the other hand, the corticosterone content of the gland was much increased after feeding with each amino acid. The amounts found after giving methionine and leucine were significantly greater than in the glands of rats fed on the protein-free diet, and the value for glycine-fed rats was almost so. This action of single amino acids contrasts with their insignificant effect on adrenal size and 
Table 3. Adrenal and plasma corticosterone levels after i I days feeding on a protein-free diet supplemented with various proteins and amino acids

(Each entry is the mean result for six male rats)

\begin{tabular}{|c|c|c|}
\hline Addition to protein-free diet & $\begin{array}{l}\text { Total adrenal } \\
\text { corticosterone } \\
\text { content } \\
\text { ( } \mu \mathrm{g} / \mathrm{I} 00 \mathrm{~g} \text { initial } \\
\text { body-weight) }\end{array}$ & $\begin{array}{c}\text { Plasma } \\
\text { corticosterone } \\
(\mu \mathrm{g} / \mathrm{I} \text { - } \mathrm{ml} \\
\text { plasma })\end{array}$ \\
\hline None & $1 \cdot 3$ & 70 \\
\hline Casein & $2 \cdot 4^{*}$ & I 24 \\
\hline Zein + try + lys & $2 \cdot 4^{*}$ & $9 \mathrm{I}$ \\
\hline Zein & $1 \cdot 3$ & 83 \\
\hline Gelatin & $\mathrm{I} \cdot 2$ & 77 \\
\hline Glycine & $2 \cdot 3$ & 99 \\
\hline Methionine & $2.4 *$ & 96 \\
\hline Leucine & $2 \cdot 5 *$ & IOI \\
\hline Standard deviation & \pm 0.93 & \pm 46 \\
\hline $\begin{array}{l}\text { Smallest difference } \\
\text { significant at } 5 \% \text { level }\end{array}$ & $I \cdot \mathbf{I}$ & 54 \\
\hline
\end{tabular}

* Significantly different $(P<0.05)$ from mean for group on protein-free diet.

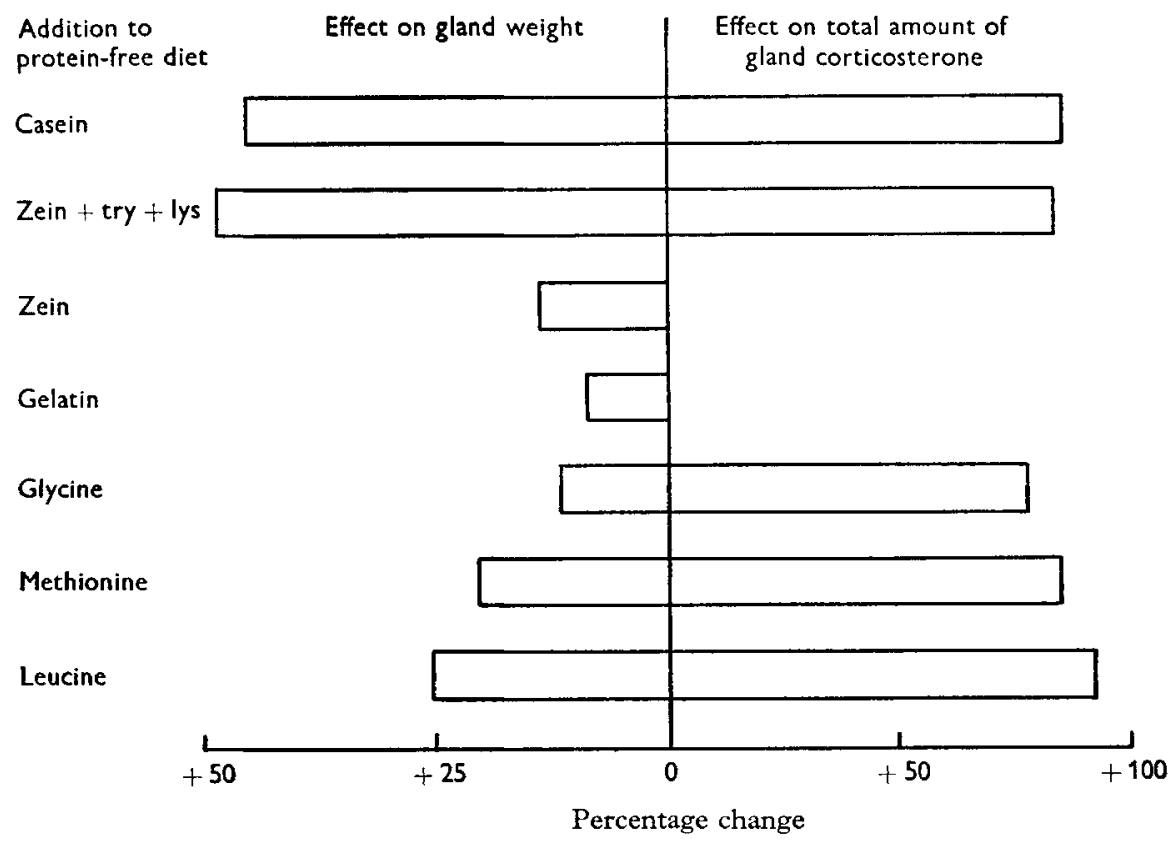

Fig. x. Comparison of percentage changes in the weight and corticosterone contents of rat adrenal glands after different proteins and amino acids had been added to a protein-free diet for an I I-day period. The animals are those described in Table 3, in which the total amounts of corticosterone in their adrenal glands are recorded. Each dietary group consisted of six male rats. The percentage changes caused by feeding with each nitrogen source were obtained by comparing the weights and total corticosterone contents of the two glands, expressed per roo $\mathrm{g}$ initial body-weight, with the weights and corticosterone contents of glands obtained from rats fed on the protein-free diet alone. 
composition (Table 2). Values obtained in the experiment reported in Table 3 for the weight and corticosterone contents of the adrenal glands of animals fed on different nitrogen sources have been computed as percentage changes from the average values found in animals given the protein-free diet. This shows that single amino acids are as effective as nutritionally complete proteins at increasing the total corticosterone content of the gland, but are much less effective at increasing gland weight (Fig. I).

Plasma corticosterone concentrations after different diets showed trends similar to those observed in the adrenal gland, but the changes failed to reach statistical significance (Table 3).

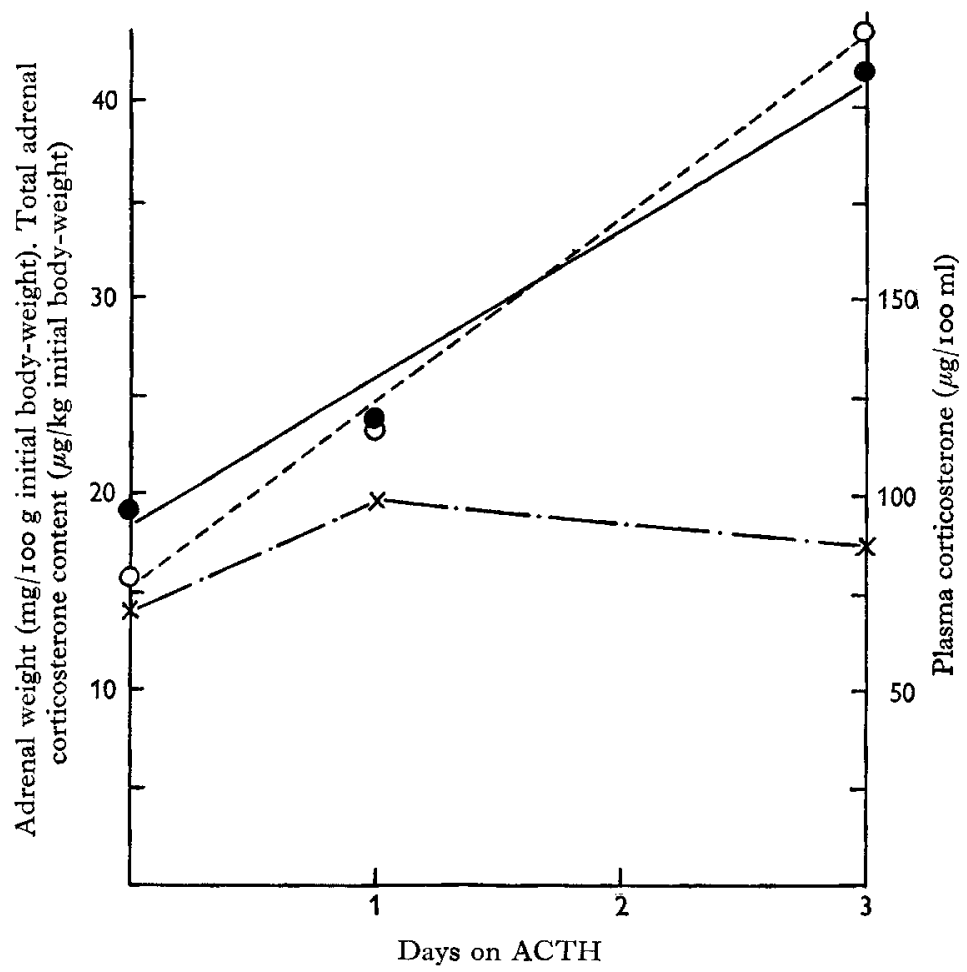

Fig. 2. Changes in the weight $(--)$ ) and total corticosterone content $(0-\ldots)$ of the two adrenal glands, and in the corticosterone content of the plasma $(x--x)$ of male rats fed on a protein-free diet and injected with adrenocorticotrophic hormone. The values are the mean results obtained for from two to four rats killed at each time interval.

\section{Action of adrenocorticotrophic hormone on the size and corticosterone content of the adrenal gland}

In view of the lack of association between changes in corticosterone content and gland weights after addition of single amino acids to a protein-free diet, a study was made of the action of ACTH on the weights and corticosterone contents of adrenal glands obtained from rats eating a protein-free diet. The hormone was administered for a 3-day period after 8 days on the protein-free diet; rats were killed at $O, I$ and 3 days. Fig. 2 shows that organ weights and total steroid contents increased simultaneously during the 3 -day period of administration of the pituitary hormone. The 
increments in gland size and corticosterone content observed after feeding with casein or with zein supplemented with tryptophan and lysine thus resembled those caused by ACTH. The increase in corticosterone content without a significant change in gland size and composition after amino acid administration distinguishes it from the effects of ACTH on the gland.

The plasma level of corticosterone showed much smaller changes on administration of ACTH (Fig. 2). The concentration rose from an initial value of $70 \mu \mathrm{g} / \mathrm{roO} \mathrm{ml} \mathrm{plasma}$ to $99 \mu \mathrm{g}$ on the Ist day, but fell to $84 \mu \mathrm{g}$ by the $3^{\text {rd }}$ day. This shows that changes in adrenal size and corticosterone content are more sensitive to ACTH administration than is blood steroid concentration.

\section{Liver composition after giving different nitrogen sources}

Munro \& Mukerji (1958) observed significant changes in liver composition $18 \mathrm{~h}$ after rats had been given single large doses of glycine, methionine or leucine. It was therefore of interest to determine whether rats fed on these amino acids over longer periods would show alterations in liver composition. The livers of the rats used to study the action of diet on adrenal cell composition (Table 2) were accordingly analysed for protein, RNA, DNA and phospholipid contents, the results being expressed as the total amounts of these constituents per $100 \mathrm{~g}$ initial body-weight (Table 4).

\section{Table 4. Liver composition after I I days feeding on a protein-free diet supplemented with various proteins and amino acids}

(Each entry is the mean result for ten female rats)

\begin{tabular}{|c|c|c|c|c|c|}
\hline \multirow[b]{2}{*}{$\begin{array}{l}\text { Addition to } \\
\text { protein-free diet }\end{array}$} & \multirow[b]{2}{*}{$\begin{array}{c}\text { Initial } \\
\text { body-weight }\end{array}$} & \multicolumn{4}{|c|}{ Liver composition/100 g initial body-weight } \\
\hline & & $\begin{array}{l}\text { Protein } \\
(\mathrm{mg} \mathrm{N})\end{array}$ & $\begin{array}{c}\text { RNA } \\
\text { (mg P) }\end{array}$ & $\begin{array}{l}\text { Phospholipid } \\
\text { (mg P) }\end{array}$ & $\begin{array}{r}\text { DNA } \\
(\mathrm{mg} \mathrm{P})\end{array}$ \\
\hline None & I 43 & $64 \cdot 2$ & 2.55 & $2 \cdot 83$ & 0.98 \\
\hline $\begin{array}{l}\text { Casein } \\
\text { Zein + try + lys } \\
\text { Zein } \\
\text { Gelatin }\end{array}$ & $\begin{array}{l}144 \\
145 \\
146 \\
145\end{array}$ & $\begin{array}{l}98 \cdot 2^{*} \\
96 \cdot 1 * \\
76 \cdot 8^{*} \\
73 \cdot 9\end{array}$ & $\begin{array}{l}3 \cdot 02 * \\
2 \cdot 93^{*} \\
2 \cdot 5^{6} \\
2 \cdot 81\end{array}$ & $\begin{array}{l}3 \cdot 96^{*} \\
3.93^{*} \\
3 \cdot 14 \\
3 \cdot 04\end{array}$ & $\begin{array}{l}0.96 \\
0.94 \\
0.90 \\
0.96\end{array}$ \\
\hline $\begin{array}{l}\text { Glycine } \\
\text { Methionine } \\
\text { Leucine }\end{array}$ & $\begin{array}{l}140 \\
145 \\
148\end{array}$ & $\begin{array}{l}77 \cdot 2 * \\
69 \cdot 7 \\
63 \cdot 3\end{array}$ & $\begin{array}{l}2 \cdot 85 \\
2 \cdot 46 \\
2 \cdot 41\end{array}$ & $\begin{array}{l}3 \cdot 20 \\
2 \cdot 81 \\
2 \cdot 59\end{array}$ & $\begin{array}{l}1.01 \\
0.90 \\
0.84\end{array}$ \\
\hline Standard deviation & - & $\pm \mathrm{I2} \cdot 8$ & \pm 0.39 & \pm 0.44 & \pm 0.11 \\
\hline $\begin{array}{l}\text { Smallest difference } \\
\text { significant at } 5 \% \text { level }\end{array}$ & - & II $\cdot 4$ & 0.35 & 0.39 & 0.10 \\
\hline
\end{tabular}

* Significantly different $(P<0.05)$ from mean for group on protein-free diet.

The feeding with casein or with zein supplemented with tryptophan and lysine significantly increased the amounts of protein, RNA and phospholipid in the liver compared with values for the animals receiving the protein-free diet. Unsupplemented zein and gelatin did not significantly change the amounts of RNA and phospholipid, although the small increase in the liver protein content of the group fed on zein attained significance. The effects of dietary proteins on liver composition were 
thus related to their nutritive values, in agreement with the observations of other investigators (Campbell \& Kosterlitz, 1948; Henry, Kosterlitz \& Quenouille, I953; Allison, 1964). None of the amino acids added to the diet caused significant increases in liver RNA or phospholipid content above the level observed in the group receiving the protein-free diet; glycine induced a small but significant increment in liver protein content (Table 4). The DNA content of the liver was not significantly influenced by any of the nitrogen sources.

\section{DISCUSSION}

The experiments now reported confirm that the weight and composition of the adrenal gland of the rat is infuenced to a considerable extent by the protein content of the diet. Animals fed for I I days on a diet containing an adequate amount of casein had adrenal glands that were $33 \%$ heavier than the glands of animals fed on isocaloric amounts of a protein-free diet (Table 2). 'The two groups, which had initially the same average body-weight, differed by only $11 \%$ in weight at the end of the experiment. This agrees with our previous observation (Munro et al. 1962) that a short period of protein deficiency has a greater effect on adrenal weight than on body-weight.

The influence of protein intake on the adrenal gland is largely determined by its nutritive value; there is little or no response in adrenal weight, general composition or corticosterone content when nutritionally inadequate proteins are added to the proteinfree diet (Tables 2 and 3 ). Since the effect of protein intake on the adrenal gland appears to depend on variations in ACTH secretion (Munro et al. I962), it can be concluded that the pituitary gland is sensitive to the amount and quality of dietary protein.

The action of large doses of single amino acids provides a different picture. The size and general composition of the gland show little change after administration of glycine, methionine or leucine, whereas corticosterone content is affected as extensively by these amino acids as by feeding with casein (Table 2 and Fig. $\mathbf{I}$ ). This is unlike the action of $\mathrm{ACTH}$, which increases both gland weight and steroid content (Fig. 2). Dissociation of weight change from steroid production has also been noted after administration of the synthetic compound norethandrolone to mice. Although it causes an increase in steroid production, it does not alter adrenal weight (Kitay \& Coyne, 1964). The possibility that amino acids have a direct influence on adrenal steroid production was explored by us in experiments not reported here. Although addition of ACTH to slices of rat adrenal gland stimulated the in vitro release of corticosterone, no increase in steroid production resulted from incubation of adrenal tissue in media containing amino acids at ten times the levels found in rat plasma. There is therefore no evidence of a direct action of amino acids on the gland.

It is well established that the amounts of RNA and protein in the liver increase after administration of cortisone (Goodlad \& Munro, 1959). This is the basis of the mechanism proposed by us to explain why uptake of ${ }^{32} \mathrm{P}$ by liver RNA is increased at I $8 \mathrm{~h}$ after the giving of a single dose of methionine or leucine to normal rats, but not to adrenalectomized rats (Munro \& Mukerji, 1962). It might be expected that repeated administration of these amino acids would lead to a considerable increase in the amounts of RNA and protein in the liver. However, the experiments reported here 
show that the giving of these amino acids over an II-day period did not lead to significant changes in liver composition (Table 4), in spite of the increase in steroid content of the adrenal gland (Table 3 ). This demonstrates that stimuli sufficient to produce changes in adrenal steroid content may not cause an increase in circulating corticosterone large enough to induce significant alterations in gross liver composition. This conclusion is in agreement with the results for adrenal and plasma corticosterone levels obtained after injection of ACTH. Although gross changes in the size and corticosterone content of the gland were produced, only minimal changes in plasma corticosterone contents accompanied these effects (Fig. 2).

\section{SUMMARY}

I. Rats were fed for I I days on diets in which the source of nitrogen was either casein, or zein supplemented with tryptophan and lysine, or unsupplemented zein, or gelatin, or the single amino acids glycine, methionine or leucine. The effects of these diets on adrenal weight, cell composition and corticosterone content were investigated

2. Compared with control rats fed on a protein-free diet, animals receiving casein or zein supplemented with tryptophan and lysine had considerably larger adrenal glands, the average adrenal cell contained more protein and RNA, and there was more corticosterone in the gland. Unsupplemented zein caused smaller changes in gland composition, but failed to increase its corticosterone content. Feeding with gelatin had no significant action on gland size, composition or corticosterone content. Thus the effects of different dietary proteins on the adrenal gland are largely determined by their nutritive value.

3. The giving of large amounts of glycine, methionine or leucine as the dietary source of nitrogen led to extensive increases in total corticosterone content of the adrenal gland without corresponding increments in gland weight.

4. Administration of adrenocorticotrophic hormone to rats on a protein-free diet caused increments of similar magnitude in gland size and in corticosterone content. From this and other evidence, it has been concluded that dietary protein influences adrenal size and steroid content through variations in rate of adrenocorticotrophic hormone secretion. Since the action of single amino acids on the adrenal gland results in accumulation of corticosterone without an increase in gland size, this effect may occur through a mechanism other than alteration in adrenocorticotrophic hormone secretion.

5. The livers of animals receiving the various nitrogen sources were analysed for protein, nucleic acids and phospholipids. There was no evidence that the accumulation of corticosterone in the adrenal glands of animals fed on amino acids caused changes in liver composition.

This work was supported by a grant from the Advisory Committee for Medical Research of the Scottish Home and Health Department, and by a grant for scientific assistance from the Medical Research Council, for which the authors are grateful. 


\section{REFERENCES}

Allison, J. B. (1964). In Mammalian Protein Metabolism. Vol. 2, p. 4I. [H. N. Munro and J. B. Allison, editors.] New York: Academic Press Inc.

Braunsberg, H. \& James, V. H. T. (1960). Analyt. Biochem. I, $45_{2}$.

Campbell, R. M. \& Kosterlitz, H. W. (1948). F. Physiol. 107, 383.

Donaldson, H. H. (I924). The Rat. Philadelphia, Pa: Wistar Institute (Memoir no. 6).

Goodlad, G. A. J. \& Munro, H. N. (I959). Biochem. F. 73, 343.

Góth, A., Lengyel, L., Bencze, E., Sávely, C. \& Majsay, A. (1955). Experientia, r1, 27.

Henry, K. M., Kosterlitz, H. W. \& Quenouille, M. H. (1953). Brit. F. Nutr. 7, 5 I.

Kitay, J. I. \& Coyne, M. D. (1964). Fed. Proc. 23, 250.

Munro, H. N. (1949). F. Nutr. 39, 375.

Munro, H. N. (1964). In Mammalian Protein Metabolism. Vol. I, p. 38r. [H. N. Munro and J. B. Allison, editors.] New York: Academic Press Inc.

Munro, H. N., Hutchison, W. C., Ramaiah, T. R. \& Neilson, F. J. (1962). Brit. F. Nutr. 16, 387.

Munro, H. N. \& Mukerji, D. (1958). Biochem. F. 69, 32 I.

Munro, H. N. \& Mukerji, D. (1962). Biochem. F. 82, 520.

Munro, H. N. \& Naismith, D. J. (r953). Biochem. F. 54, rgr.

Munro, H. N., Steele, M. H. \& Hutchison, W. C. (1963a). Nature, Lond., r99, I I8z.

Munro, H. N., Steele, M. H. \& Hutchison, W. C. $\left(\mathrm{rg6}_{3} b\right)$. Proc. Nutr. Soc. 22, xxxiii.

Silber, R. H., Busch, R. D. \& Oslapas, R. (1958). Clin. Chem. 4, 278.

Thomson, R. Y., Heagy, F. C., Hutchison, W. C. \& Davidson, J. N. (1953). Biochem. F. 53, 460. 